\title{
Media en oorlog
}

Inleiding

\section{Bernadette Kester \& Huub Wijfjes}

Bij alle internationale conflicten van de moderne tijd waren de media prominent anwezig. De Golfoorlog, Rwanda, Bosnië, Kosovo en OostTimor zijn onverbrekelijk verbonden met de beelden en verhalen die de media construeerden. Zij brachten nieuws, gaven daar kleuring en interpretatie aan en hielden de politiek en de militairen binnen de hun toegestane bewegingsvrijheid nauwlettend in de gaten. Al doende vormden ze een factor van betekenis in de politieke, soms ook militaire besluitvorming. Over de waarde daarvan zijn de meningen verdeeld. 'We worden soms wat al te gemakkelijk op sleeptouw genomen door de berichtgeving van de media', schreef de Nederlandse minister van buitenlandse zaken Jozias van Aartsen in september 1999 op de opiniepagina van NRC Handelsblad.

'De kwaliteit van de berichtgeving laat steeds meer te wensen over. (...) De druk van de hoofdredacteur om een scoop te maken wordt steeds groter. Dat betekent dat de traditionele hoor- en wederhoor steeds minder wordt toegepast. Het nieuws krijgt zo steeds meer soapgehalte. (...) Effectief buitenlands beleid kan niet gebaseerd zijn op primaire emoties."

Het is een oude klacht van politici, diplomaten en militairen. Zolang er oorlogen zijn, bestaat er angst, wantrouwen en verontwaardiging over de zelfstandige rol die boodschappers of media in een cruciale tijd op hun terrein kunnen spelen. Journalisten zouden door hun werkzaamheden niet alleen militairen en politici soms letterlijk voor de voeten lopen, maar het publiek ook een eenzijdig, vertekend of zelfs verkeerd beeld geven van wat er werkelijk gebeurt. Daardoor zouden ze de bevolking kunnen demoraliseren, ophitsen of in verwarring brengen. Ook zouden ze de oorlogsinspanning ondermijnen, tegenwerken of belachelijk maken.

Maar ook bij de media zelf leiden oorlogen tot klaagzangen. Vooral de mediamanipulatie door autoriteiten wordt als vernederend en schadelijk ervaren door journalisten die zichzelf zien als de waakhond van de democratie en/of de vertolkers van de publieke opinie. Zo interpreteerde 
Elsbeth Etty de eerder aangehaalde mening van minister Van Aartsen als een oproep de waarheid niet onder ogen te willen zien. Met de tendentieuze historische analogie Wir haben es nicht gewusst typeerde ze Van Aartsens pleidooi als 'niet-emotioneel, tot op het bot amoreel en fundamenteel onverschillig staatsmanschap'. ${ }^{2}$ Het is een reactie die logisch past in het journalistieke discours van de laatste halve eeuw. 'The first casualty when war comes is truth', wordt daarin als metafoor gekoesterd.' Maar deze uitspraak uit 1917 van een Amerikaanse senator verwees niet alleen naar de strenge censuur tijdens de Eerste Wereldoorlog, maar sloeg ook op de bereidwilligheid van oorlogsverslaggevers om de 'waarheid' te offeren ten gunste van de nationale eer en militaire moed. De Grote Oorlog was niet de eerste oorlog waar de beroepseer van verslaggevers op de proef werd gesteld en zeker niet de laatste. Zo werden vooral de Falklandoorlog en de Golfoorlog als de voorlopige dieptepunten voor het journalistieke metier ervaren. Niet zozeer vanwege de eigen 'offervaardigheid' maar vanwege de absurd strenge regie van militaire en politieke machthebbers. Het beeld dat van beide oorlogen in de media naar voren kwam, was zelfs dermate gemanipuleerd dat de Franse postmoderne denker Jean Baudrillard een essay schreef onder de absurdistische en provocerende titel 'The Gulf War did not take place'. ${ }^{4}$

Oorlogen mogen politiek, leger en media blijkbaar terugwerpen op de basisvragen van hun functioneren en onderling verkeer, het is ronduit opvallend hoe versimpeld deze vragen vervolgens een antwoord vinden, ook in de wetenschap. Dit themanummer van het Tijdschrift voor Mediageschiedenis beoogt daar iets aan te doen. Aan de hand van een gevarieerd aantal studies en boekrecensies worden verschillende gezichtshoeken belicht waarmee de complexe relatie van media en politiek in internationale conflicten kan worden benaderd. Centraal daarin staat de sinds het midden van de negentiende eeuw gevormde relatie tussen publieke opinie, media, (internationale) politiek en beeldvorming.'

\section{Publieke opinie}

Mediahistorici zijn geneigd de zelfstandige macht van media in politiek en cultuur in verband te brengen met de opkomst van de massapers aan het eind van de negentiende eeuw en vooral met de overweldigende opmars van audiovisuele media sinds het begin van de twintigste eeuw. De media met een massale verspreiding - populaire kranten en tijdschriften, film, fotografie, radio en televisie - zouden een ongekende macht hebben over wat men gewoonlijk 'de massa' noemde. Het is niet voor niets dat in de eerste decennia van de twintigste eeuw het fenomeen publieke opinie, 


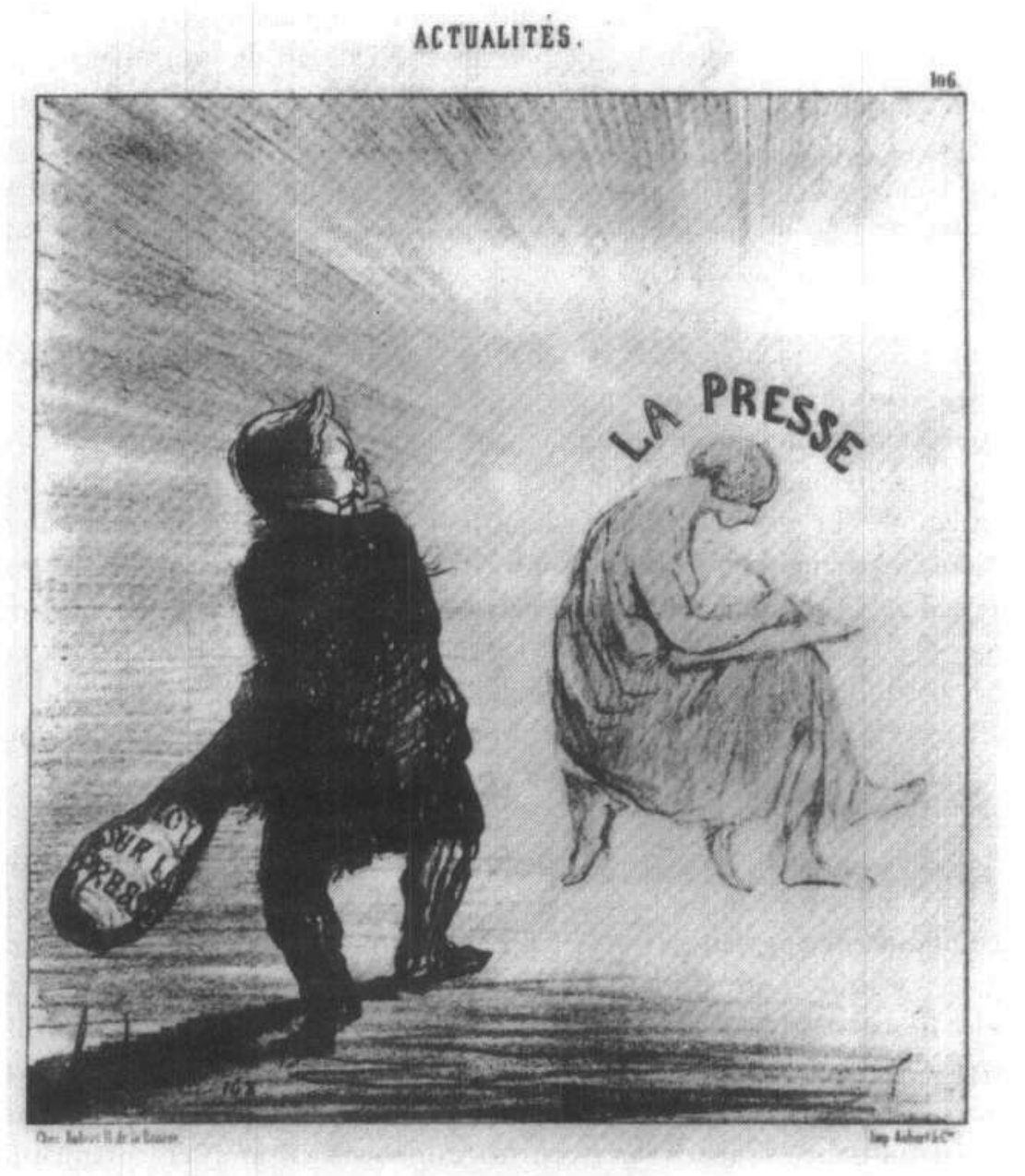

De politicus Thiers probeert de pers het zwijgen op te leggen

Bron: J.R. Kist,

Daumier, verslaggever van zijn tijd, 1832-1872, Antwerpen/Utrecht 1971

dat reeds in de achttiende eeuw werd 'ontdekt', in hevige belangstelling van politiek en wetenschap kwam te staan. ${ }^{6}$ Een van de interessantste zaken waarop het publieke-opinieonderzoek de aandacht heeft gevestigd, is de rol van de mediaproducenten. Zij namen niet herkenbaar deel aan politieke of diplomatieke besluitvorming, maar rapporteerden daarover wel in de openbare sfeer. Die rapportage bepaalde vervolgens de toon en de richting van het openbare debat, soms sterker dan politici en diplomaten wenselijk achtten.

Het was vooral toen de media vanaf de tweede helft van de negentiende eeuw een andere verhouding schiepen tussen politiek, publiek en openbaarheid dat de pers als een zelfstandige factor in crises, zoals oorlogen, begon te verontrusten. De vanaf 1850 zich ontwikkelende commerciële massapers wenste immers een anoniem massapubliek met een lage 
politieke interesse te bereiken. Journalisten van massakranten brachten het nieuws daarom dicht bij de belevingswereld van de individuele lezer in een simpele en overzichtelijke vertelstructuur. Ze formuleerden niet, zoals de traditionele politieke pers dat sinds de achttiende eeuw had gedaan, een herkenbaar en beargumenteerd standpunt, maar reageerden emotioneel en impulsief. Al doende ontdekten ze de attentiewaarde van het crisisgevoel voor het lezerspubliek. Hoge oplages konden worden bereikt als kranten een gevoel uitten van bedreiging door ongrijpbare en onvoorspelbare krachten zoals criminaliteit, ziekte, natuurgeweld, technisch falen, corruptie, uitbuiting en oorlog. Kranten begonnen te schrijven over conflicten, bedreigingen en angsten in metaforen, overdrijvingen en abstracties die niet appelleerden aan rationele argumenten maar aan gevoel en emotie. Er was niet meer gewoon moord en doodslag, maar er waren moordmysteries en misdaadgolven waarin syndicaten en baronnen een rol speelden. De besmettelijke ziekte werd een epidemie die als een virus de mensheid teisterde, dalende aandelenkoersen leidden tot beurspaniek en het corrupte gedrag van politici, militairen en tycoons werd ingedeeld in affaires en schandalen. In de rusteloze zoektocht naar nieuwe affaires ontstond onder het motto 'the people's right to know' een geheel nieuw beroep: onderzoeksjournalist.?

Zoals blijkt uit het artikel van Marcel Broersma (zie p. 40) over de Nederlandse pers in de Eerste Wereldoorlog, werd in Nederland tegen de popularisering van de pers succesvol tegenwicht geboden door zelfregulering in de journalistiek. Daarin speelde de verzuiling een rol, maar niet de belangrijkste. Binnen de beroepsgroep der journalisten ontwikkelde zich een standsbesef dat op gespannen voet stond met, wat men noemde, 'sensatiejournalistiek' en 'Amerikaanse toestanden'. Vooraan staan bij gebeurtenissen met een hoge nieuws- en amusementswaarde -branden, rampen en moord- en doodslag - was geen houding die hogelijk werd geprezen. Ook het graven naar misstanden en schandalen waarbij leidende figuren waren betrokken, stond in een kwade reuk. De onderzoeksjournalistiek vond in Nederland dan ook slechts op bescheiden schaal navolging.

\section{Media in internationale conflicten}

De macht van de publieke opinie en de media die haar vertolkten, bleek in eerste instantie bij internationale crises. In de Spaans-Amerikaanse oorlog om Cuba in 1898 bleek dat massamedia een stemming konden scheppen die politici dwong tot een reactie, omdat hun politiek mandaat in toenemende mate afhing van de steun van de massa. Hoewel modern 
onderzoek heeft uitgewezen dat de invloed van de pers niet moet worden overdreven, is de rol van de massapers (met name van uitgever William Randolph Hearst) in het uitbreken van de oorlog met Spanje een zeer opvallende politieke vernieuwing. ${ }^{8}$ De oorlog, die Engeland tussen 1898 en 1902 met de Zuid-Afrikaanse Boeren uitvocht, toonde voor het eerst ook de kracht van fotografie en film. Foto's van platgebrande boerenhuizen, maar vooral die van vrouwen, kinderen en bejaarden die in mensonterende concentratiekampen waren opgesloten, veroorzaakten in Europa een anti-Engelse stemming die het Engelse leger dwong tot controle op de media. ${ }^{9}$ Men begon eisen te stellen aan de bewegingsvrijheid van journalisten, fotografen en filmers, maar ook werden de eerste pogingen gedaan om zelf mediaproducten te vervaardigen die het beeld van de oorlog in voor het leger gunstige zin bij zouden moeten stellen. Tijdens latere oorlogen zouden legers naast een militaire ook een mediastrategie ontwikkelen.

Overigens bleek dat in de meeste gevallen de media weliswaar een zelfstandige factor in oorlogen en crises vormden, maar dat ze in landen waar ze vrij konden opereren het officiële beleid weinig tot niets in de weg legden. Integendeel, tijdens de Eerste en Tweede Wereldoorlog en nog geruime tijd daarna steunden de media in overweldigende mate de oorlogsinspanning van hun eigen land, zonder dat daarvoor de ernstige dwang, censuur of manipulatie nodig was die zo kenmerkend was voor dictatoriale regimes. ${ }^{10}$ Zoals ook blijkt uit het overzichtsartikel van Jan Schoeman (zie p. 16) veranderde dat patroon in de jaren zestig door een toenemende kritische autonomie in de mediawereld en door de invloed van de televisie. De oorlog in Vietnam werd de eerste waarvan vrijwel dagelijkse beelden waren te zien bij de mensen thuis. De Amerikaanse overheid bemerkte voor het eerst de consequentie hiervan voor het gevoel dat kijkers over de oorlog kregen. De televisie legde een grotere nadruk op het belang van de individuele mens en zijn emotie. De televisie deed immers een beroep op vrijwel alle zintuigen tegelijkertijd en was bovendien gestructureerd in tijd, wat wil zeggen dat televisie niet zoals een krant of tijdschrift naar believen kon worden gelezen of teruggebladerd. Ze walste in één ruk over de kijker en appelleerde eerder aan diens verlangen emotioneel geprikkeld en vermaakt te worden met sterk herkenbare en invoelbare beelden en geluiden.

Uit de soms schokkende beelden die op de Amerikaanse televisie waren te zien en de publieke verontwaardiging die als gevolg daarvan ontstond, trok de Amerikaanse legerleiding conclusies waaruit de zogenaamde 'Vietnam-mythe' is voortgekomen. Omdat het voor haar ondenkbaar was dat het machtige Amerikaanse leger verslagen zou kunnen zijn door een onbeduidend guerrilla-leger uit een derdewereldland, moest 
de oorzaak van de nederlaag wel liggen bij een tekort aan steun bij het thuisfront. De media, de televisie voorop, zouden de bereidheid van de Amerikaanse bevolking om de oorlog te steunen hebben ondergraven, vooral na het Tet-offensief van 1968. Vanaf die tijd zou de televisie hebben gefocust op slachtoffers en ellende, op hopeloosheid en onmenselijkheid en zou de pers (bijvoorbeeld de New York Times met de publicatie van The Pentagon Papers) vraagtekens zijn gaan stellen bij de rechtmatigheid en rechtvaardigheid van het regerings- en legerbeleid. De media begonnen eenzijdig de acties van de anti-oorlogsbeweging voor het voetlicht te brengen. Dat alles culmineerde in een defaitisme dat de bereidheid de oorlog voort te zetten ernstig aantastte."

Deze eenvoudige interpretatie, die lijkt op de dolkstoot-legende die Duitse nationalisten in het interbellum ter verklaring van het Duitse verlies in de Eerste Wereldoorlog formuleerden, is inmiddels bijgesteld op grond van onderzoek door historici en communicatiewetenschappers. Het sleutelwerk in dit verband is ongetwijfeld The 'Uncensored War' van de politicoloog Daniel C. Hallin, die de inhoud van de New York Times en de televisiejournaals analyseerde en daaruit de conclusie trok dat deze media eerder de stemming onder de bevolking hebben gevolgd dan bepaald." Pas toen na veel aarzeling de eerste beelden werden uitgezonden van dode en verminkte Amerikaanse soldaten en de wandaden tegen de Vietcong en de burgerbevolking aan het licht kwamen, keerden de Amerikaanse media zich tegen de oorlogsinspanning, maar niet eens in meerderheid. De publieke steun voor de Vietnam-politiek bleef ook vrijwel tot het eind in 1975 bestaan.

\section{Het CNN-effect}

Ondanks bovengenoemde nuanceringen over de invloed van media, zit sinds de ervaringen met de Vietnamoorlog de schrik er goed in bij politici, diplomaten en militairen. $\mathrm{Zij}$ kijken vooral met zorg naar de neiging van media om oorlogen, conflicten of crises vanuit het menselijk of moreel perspectief te benaderen. Gezagsdragers die vanuit politieke, militaire en strategische overwegingen wensen te handelen in besloten circuits, voelen zich gehinderd dan wel in ongunstige posities geplaatst door wat wel eens de 'CNN-curve' of 'dubbelzinnige media-angst' wordt genoemd. Met name sinds televisienieuwsproducent CNN vanaf 1980 een imposant wereldwijd netwerk van 24-uursnieuwszenders heeft opgebouwd en zich tevens een belangrijke positie veroverde in de internationale nieuwsbeeldenmarkt, is sprake van live meebeleven van conflicten, misstanden en oorlogen overal ter wereld. Dientengevolge krijgt een gemiddelde kijker 
steeds meer verslaggeving te zien van misdaden of misstanden die hij niet uit eigen ondervinding, maar via het televisiescherm beleeft. De dramatische CNN-beelden en het daaraan gekoppelde crisiswoordgebruik wekken verontwaardiging of schuldgevoelens op. Niet zelden leiden die tot aandrang om militair dan wel humanitair hulp te bieden.

Maar er is een andere kant aan de 'dubbelzinnige media-angst'. De verslaggeving van de consequentie van een militaire interventie - vooral de daarbij vrijwel onvermijdelijke slachtoffers - ondermijnt de publieke steun voor interventie vrijwel onmiddellijk weer. Zo noopten de beelden van hongersnood en burgeroorlog in Somalië begin jaren negentig acuut tot Amerikaanse interventie, om een einde te maken aan mensonterende praktijken. Maar de beelden van verminkte Amerikaanse soldaten die door de straten van Mogadishu werden gesleept, noopten even acuut en hard tot terugtrekking. De symbolische beelden van hongerende Somalische kinderen werden op slag ingeruild voor even symbolische beelden van dorstige Amerikaanse soldaten met een wanhopige blik in de ogen.

Ook de westerse interventie in de Bosnië-crisis (1992-1996) laat dergelijke media-invloed zien. Zo was in de zomer van 1994 bij de BвC een gefilmd portret te zien van het stervende weesmeisje Irma Hadzimuratovic. Het 'emotionele succes' van deze reportage leidde tot een hele reeks Bosnische weesmeisjes op televisie. Premier Major zag zich gedwongen de luchtbrug Operation Irma te beginnen. Dit voorbeeld wijst erop dat journalisten de in principe onbegrensde hoeveelheid nieuws voor zichzelf en het publiek betekenis geven door overzichtelijke kaders (in communicatiewetenschappelijk termen: frames) te construeren, waarin feiten worden gerangschikt waarvan de journalisten aannemen dat ze de hoogste nieuwswaarde hebben. Frames kennen veelal slechts een eenduidige betekenis of perspectief. De oorlog wordt bijvoorbeeld alleen vanuit de beleving van deelnemers aan de oorlog of vanuit een bepaalde morele positie weergegeven. Korte fragmenten videobeeld, die steeds worden herhaald, illustreren die betekenis bij televisie in de meest krachtige vorm. Arthur ten Cate toont in zijn bijdrage aan hoezeer metaforen en historische analogieën bij de geschreven pers een rol in de berichtgeving van oorlogen spelen (zie p. 100). ${ }^{14}$

De ontdekking van Servische krijgsgevangenenkampen bij de Bosnische plaatsjes Trnopolje en Omarska in augustus 1992 werd geheel ingekaderd als het mogelijk begin van genocide in concentratiekampen. Door te verwijzen naar de holocaust, nazi-praktijken en het westerse schuldbesef over München 1938, werd de druk op de Navo om in te grijpen aanzienlijk vergroot. De gerenommeerde Amerikaanse politicoloog en buitenlandspecialist Bernard Cohen vertolkte in een bundel over de relatie tussen publieke opinie, media en buitenlands beleid de mening van vele militairen over dergelijke frames: 
Tekening van Len Munnik, die commentaar levert op het beeld van de 'schone, effectieve' oorlog dat de westerse mogendheden wilden presenteren. Bron: Len Munnik, Prinsenbeek

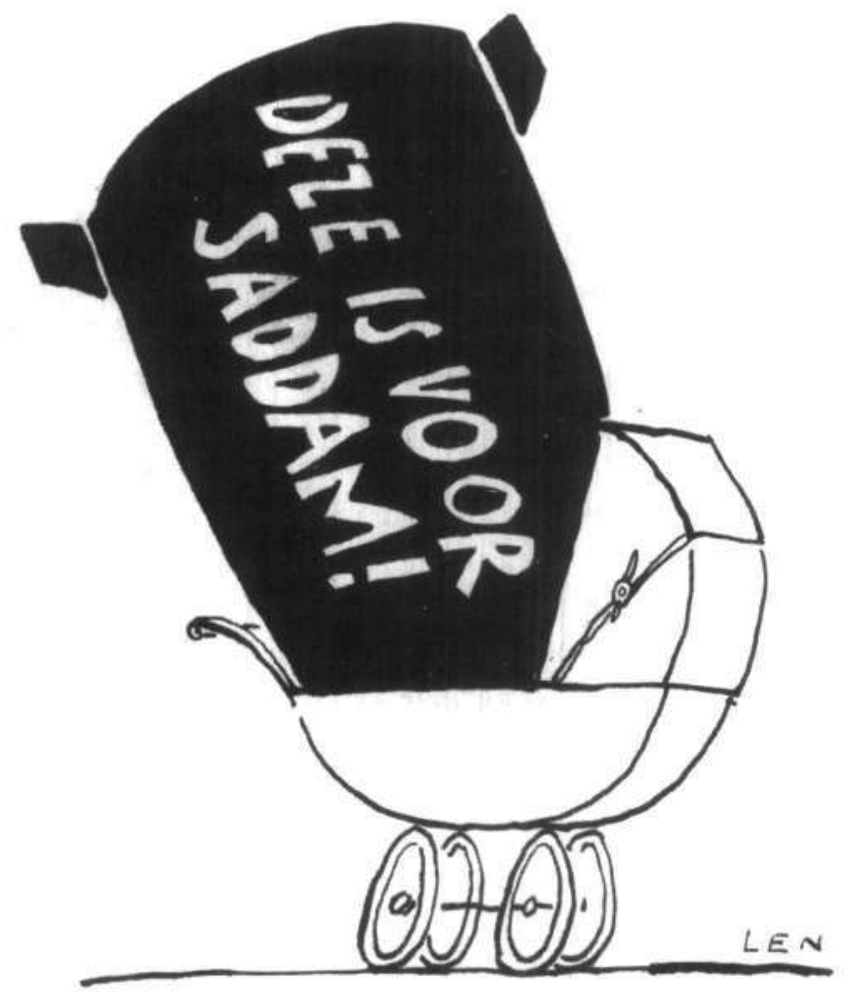

'By concentrating almost exclusively on the eminently pictorial humaninterest aspects of the fighting in Bosnia-Herzegovina - people freezing in unheated nursing homes in Serajevo, children caught in smallarms fire, children separated from their families, emaciated men behind barbed-wire - television has stimulated a more active American (and international) consideration of interventionary policies in the former Yugoslavia." ${ }^{\text {"s }}$

Waar of niet waar - systematisch-vergelijkend onderzoek naar beeldvorming van verschillende mediasoorten is niet het sterkste punt van de mediawetenschap - televisiejournalistiek is een realiteit waarmee terdege rekening gehouden moet worden. Politici en moderne westerse legers zijn dan ook steeds meer gaan proberen de mediaverslaggeving van militaire confrontaties en acties te sturen. Bij de Falklandoorlog tussen Engeland en Argentinië in 1982 werden journalisten vrijwel niet tot het strijdtoneel toegelaten. De schaarse foto's en videobeelden werden door militairen aangeleverd of konden slechts in streng gecontroleerd verband worden verzameld. ${ }^{16} \mathrm{Nu}$ was dat in een ontoegankelijk oorlogsgebied op duizenden kilometers afstand van de rest van de bewoonde wereld gemakkelijker 
dan elders. Tijdens de Golfoorlog was het systeem waarbij journalisten alleen in gecontroleerde pools hun werk mochten doen en de VN-troepenmacht dagelijks spectaculaire, zorgvuldig geregisseerde persconferenties hield, ook tamelijk 'succesvol'. Het beeld van een schone oorlog met een buitengewone effectiviteit van de westerse legers is sterker geweest dan dat van een relatief kleine trefzekerheid van de afgeworpen bommen. ${ }^{17}$ William Uricchio besteedt in een essay aandacht aan de rol die dergelijke mediatechnologie speelt in de verfijning van geleide wapens en over de invloed hiervan op de perceptie van het slagveld (zie p. 160). Hij borduurt daarbij voort op de invloedrijke ideeën van onder anderen Paul Virilio.

De manier waarop de Golfoorlog is verslagen, is een schoolvoorbeeld van pogingen tot beheersing van de verslaggeving door leger en politiek. Om die reden is het gedrag van de media en de autoriteiten in deze oorlog dan ook hevig bediscussieerd, in zowel journalistieke als wetenschappelijke kring. Journalisten richten zich daarbij vooral op de vraag in hoeverre zij zich hebben laten manipuleren door militaire en politieke autoriteiten. ${ }^{18}$ Maar misschien nog meer dan manipulatie en frustratie is de verslaglegging van de Golfoorlog een voorbeeld van de manier waarop een gebeurtenis betekenis krijgt in een voortdurend touwtrekken tussen autoriteiten die probeerden het nieuwsaanbod te reguleren en controleren, de journalistiek die vooral uit is op pasklare soundbites, verkoopbare beelden en emotie, en actie- en belangengroepen in het thuisfront die in de crisissfeer van de oorlog een mogelijkheid zien hun deelbelang voor het voetlicht te brengen.

\section{Beeld en verbeelding}

Reguleringspraktijken zoals die voorkomen in de driehoek leger-politiekpers spelen in de (westerse) populair-culturele voorstellingen van oorlogen nauwelijks een rol. Terwijl de pers die bericht over oorlog, het odium dient uit te dragen van directheid en onmiddellijkheid (samen te vatten als 'simultaneïteit') alsmede van objectiviteit en authenticiteit, worden media als film en literatuur in de eerste plaats geassocieerd met beeldvorming achteraf en met spanning, amusement en esthetisch genot, al dan niet intellectueel prikkelend. De gecreëerde tegenstelling tussen journalistieke media en populair-culturele media brengt een aantal normatieve opposities met zich mee. Zo zijn discussies ontstaan over waarheid versus vervorming, objectieve informatie versus subjectieve verhalen, reconstructie versus constructie en authenticiteit versus manipulatie.

Natuurlijk weten niet alleen mediadeskundigen, maar inmiddels ook grote delen van het publiek maar al te goed dat de zaken zeker niet zo 
strikt gescheiden liggen en dat met name op het eerste deel van de genoemde opposities wel wat valt af te dingen. Waarheid, authenticiteit, objectiviteit... wie gelooft er nog in? Iedereen, hoe paradoxaal dat ook mag klinken. Anders zouden kranten, tijdschriften, journaalbeelden en televisiereportages niet zo vaak tot uitgangspunt van onze visie op de werkelijkheid dienen. Hooguit bestaat er een Popperiaanse houding waarmee we voor wáár aannemen wat de serieuze media ons bieden, totdat die inhoud gefalsificeerd wordt en een nieuwe (voorlopige) waarheid zich andient. Een treffende illustratie daarvan levert het artikel van Chris Vos over de op grond van media-aandacht veranderende maatschappelijke discussies in Nederland aangaande de (vermeende) excessen van het Nederlandse leger tijdens de Indonesische bevrijdingsoorlog (zie p. 69). Vos laat zien dat historische beelden door processen van maatschappelijke en individuele herinnering worden gevormd.

Vos concentreert zich op het medium televisie, maar in dit verband is er ook over speelfilms een en ander te zeggen. Vooral over producties die conventiegrenzen tussen televisiereportages en speelfilms overschrijden. Stilistische ingrepen - een bepaalde cameravoering of een afwijkende montage - kunnen speelfilms over actuele of historische onderwerpen een aanzien geven dat twijfel en verwarring zaait over het genre en over het 'waarheidsgehalte' van de film. Dit is een van de aspecten die aan de orde komt in de bijdrage van Bernadette Kester (zie p. 123). Deze stilistische opposities spelen bij uitstek een rol in postmodernistische theorievorming rond historische representatie in het algemeen en die in film in het bijzonder. Igor Krstic geeft in zijn bijdrage een theoretische interpretatie van de controversiële film UNDERGROUND van de Servische regisseur Emir Kusturica. Via het gebruik van stijlmiddelen en genreconventies afkomstig uit melodrama en opera, een hoog metaforisch gehalte en voortdurende verwijzingen naar andere films alsmede naar het constructieproces van de film zelf, geeft UNDERGROUND een kritische 'lezing' van de meest traumatische gebeurtenissen uit het (ex-)Joegoslavische verleden van deze eeuw.

Speelfilms en documentaires (en alle mogelijke tussenvormen) bestrijken een ander domein dan televisiereportages en journaalbeelden. Zij kunnen daardoor zonder gevolgen - tenzij pittige discussies - spelen en schuiven met conventies en toeschouwersverwachtingen, zonder dat ze daardoor direct minder 'waar' zijn. 
In het Nederlandse historisch onderzoek dringen nieuwe inzichten over de dynamiek van media in oorlogstijd en verbeelding van oorlog na afloop van conflicten maar langzaam door. Historici zijn doorgaans buitengewoon media-naïef. Velen gaan er nog van uit dat media geen geschiedenis van belang voortbrengen, maar slechts exponenten zijn van een per definitie vluchtige en dus te verwaarlozen populaire cultuur. Dan zijn er ook historici die media gebruiken als kritiekloze illustratie van wat er speelde in een bepaald tijdvak. Media fungeren dan als een spiegel van mentaliteit en cultuur. Aan de andere kant van het spectrum bevinden zich historici die wijzen op de enorme vertekening die media gaven van wat zij, op grond van archiefonderzoek, als de historische werkelijkheid hebben gedefinieerd. Termen als propaganda en mediamanipulatie worden dan gebruikt, vooral in relatie tot duistere regimes en verwerpelijke ideologieën.

Zowel de spiegel- als de vertekeningsinterpretatie gaan uit van een werkelijkheid die ergens voor eeuwig is vastgelegd en die door historici kan worden uitgegraven mits men de juiste methode en bronnenkritiek toepast. Het is een opvatting die dicht in de buurt komt van het 'naïf empirisme' dat de professionele journalistiek sinds de negentiende eeuw kenmerkt. De werkelijkheid bestaat in die opvatting uit feiten die slechts door middel van een betrouwbare methode hoeven te worden waargenomen of verzameld om een objectieve schets van die werkelijkheid te kunnen maken. ${ }^{19}$ Hoewel dergelijke opvattingen sterk zijn uitgesleten, zowel onder journalisten als onder historici, kost het in beide werelden blijkbaar moeite om over te schakelen op een interpretatie waarbij meer oog is voor het geconstrueerde karakter van wat men doorgaans feiten noemt. Het is vooralsnog een beperkt aantal mediahistorici dat onderzoek doet naar de constructie van de werkelijkheid die media maken op grond van vormtechnische, mediumeigen en beroeps- en cultuurgebonden opvattingen, alsmede van de invloed van politiek en maatschappij daarop.

\section{Noten}

I J.J. van Aartsen, 'Buitenlands beleid moet zich niet laten leiden door CNN', in: NRC Handelsblad, 9-9-1999.

2 E. Etty, 'Emoties', in: NRC Handelsblad, II-9-1999 (zaterdagbijvoegsel).

3 P. Knightley, The first casualty. From the Crimea to Vietnam. The war correspondent as hero, propagandist and myth maker, Londen enz. 1982, p. I. Knightley, een journalist van de Sunday Telegraph, meet het handelen van 
oorlogsverslaggevers in het verleden volledig af aan de norm van de kritische en onafhankelijke journalistiek die in de jaren zeventig tot de standaard van het vak was verheven. Zie voor een minder normatieve analyse van de relatie tussen en pers en leger: T. Hoyle, War report. The war correspondent's view of battle from the Crimea to the Falklands, Londen 1987; P. Young en P. Jesser, The media and the military. From the Crimea to Desert Strike, Londen 1997.

4 J. Baudrillard, The Gulf War did not take place, Sydney I995 (oorspr. La Guerre du Golfe n'a pas eu lieu, 1991).

5 Een analyse die ook de binnenlandse politiek in de beschouwing betrekt, biedt: H. Wijfjes 'De constructie van crises. Enige inleidende beschouwingen over nieuwsdynamiek en geschiedenis', in: Groniek, Historisch Tijdschrift, 145, juli 1999, p.359-372.

6 Een sleutelwerk is: W. Lippmann, Public opinion, New York 1922. Voor een kort overzicht van de historiografie zie: H.L. Childs, De publieke opinie, Utrecht 1968.

7 R. Miraldi, Muckraking and objectivity. Journalism's colliding traditions, New York 1990.

8 Toonzettend was lange tijd: M.M. Wilkerson, Public opinion and the SpanishAmerican war. A study of war propaganda, New York 1967. Recente overzichten van standpunten bieden: I. Musicant, Empire by default. The SpanishAmerican War and the dawn of the American century, New York 1998; L. Perez jr., The War of I898. The United States and Cuba in history and historiography, Chapil Hill 1998.

9 E. Lee, To the bitter end. A photographic history of the Boer War 1899-1902, New York 1985; J. Branes, Filming the Boer War, Londen 1990.

Io Zie: P.M. Taylor, Munitions of the mind. War propaganda from the ancient world to the nuclear age, Wellingborough 1990; Idem, Global communications. International affairs and the media since 1945, Londen 1997, p. 59 e.v. Zie voor een beschouwing over dit laatste boek de recensierubriek van dit tijdschrift.

II Taylor, Global communications, p.I08-II3.

I2 D.C. Hallin, The 'Uncensored War'. The media and Vietnam, Berkeley 1989. Voor de pers zie: C.R. Wyatt, Paper Soldiers. The American press and the Vietnam war, New York enz. 1993.

I3 Over de omgang van media, het publiek en de politiek met verre geweldsconflicten, zie: M. Shaw, Civil society and media in global crises. Representing distant violence, Londen 1996.

14 Zie uitvoeriger: A. ten Cate, Sterven voor Bosnië? Het Bosnische interventiedebat: een case-study naar het gebruik van historische analogieën in de Nederlandse dagbladpers, Rijksuniversiteit Groningen (doctoraalscriptie) 1998.

I5 B.C. Cohen, 'A view from the Academy', in: W.L. Bennett en D.L. Paletz (red.), Taken by storm. The media, public opinion, and us foreign policy in the Gulf War, Chicago enz. 1994, p. Io.

I6 R. Harris, Gotcha! The media, government and the Falklands Crisis, Londen 1983; D.E. Morrison en H. Tumber, Journalists at war. The dynamics of news reporting during the Falkland Conflict, Londen 1988 . Over de media en de militaire beïnvloeding daarvan bij een groot aantal militaire interventies, zie: P.R. Young, Defence and the media in time of limited war, Portland 1992. 
17 P.M. Taylor, War and the media. Propaganda and persuasion in the Gulf War, Manchester 1992.

I8 Voor het journalistieke debat in de vs, zie: H. Smith (red.), The media and the Gulf War. The press and democracy in wartime, Washington DC 1992.

I9 Zie daarvoor: M. Schudson, Discovering the new. A social history of American newspapers, New York 1978; P. Vasterman en O. Aerden, De context van het nieuws, Groningen 1995, p. 103-120. 